\title{
Joel's Self-Redemption in the Unnatural Narrative Structure of Charlie Kaufman's Eternal Sunshine of the Spotless Mind (2004)
}

\author{
Nur Aainaa Amira Mohd Said, Arbaayah Ali Termizi*, and Mohammad Ewan \\ Awang
}

Department of English, Faculty of Modern Languages and Communication, Universiti Putra Malaysia, 43400 Serdang, Selangor, Malaysia

\begin{abstract}
This essay discusses the significance of the unnatural narrative structure in Charlie Kaufman's screenplay Eternal Sunshine of the Spotless Mind (2004). Oftentimes, the screenplay's reverse chronology is studied as a backdrop to accentuate its thematic values of personal identity and memory. However, this study argued that the reverse narrative was caused by the protagonist's self-redemption journey. To achieve this objective, two components of Kenneth Burke's dramatism theory, dramatistic pentad and guilt-redemption cycle were utilized. The pentadic analysis explored the connection between the main characters' actions and motives with the structure of the text while also interpreting the implication of its reverse narrative from the framework of guilt-redemption cycle. From the findings, the study affirms that the screenplay's unnatural narrative structure i.e. reverse chronology integrally founded the narrative structure of the text by representing Joel's regret in a sequence of guilt-redemption cycle.

ARTICLE INFO

Article history:

Received: 21 September 2020

Accepted: 2 December 2020

Published: 26 March 2021

DOI: https://doi.org/10.47836/pjssh.29.1.26

As a result, it showcases the versatility of dramatism theory as one of the analytical tools for narrative studies particularly on the unnatural narrative structure of screenplay texts.
\end{abstract}

E-mail addresses:

aainaasaid31@gmail.com (Nur Aainaa Amira Mohd Said)

arbaayah@upm.edu.my (Arbaayah Ali Termizi)

ewan@upm.edu.my (Mohammad Ewan Awang)

*Corresponding author
Keywords: Dramatistic pentad, guilt-redemption cycle, literature, screenplay, unnatural narratology 


\section{INTRODUCTION}

Narratology or the study of narrative theories is a "humanities discipline dedicated to the study of the logic, principles, and practices of narrative representation" (Meister, 2014 p. 329). It is classified in two different subjects: one that focuses on literary narratives mainly found in prose, poetry and fictions, and another one is concerned on "any kind of storytelling" such as historical writing, conversational narratives and in electronic media (Fludernik \& Pirlet, 2012, p. 225). However, following the emergence and growth of other school of criticisms which offer new parameters of literature interpretations and studies, narratology almost loses its mark in literature studies.

As a result, many narratologists began to construct new inputs for the scholarship and this resulted in two trajectories of narrative studies: classical narratology which is a technical, more "scientifically motivated" narratology that observes similarity and difference of narratives (Prince, 2008, p. $115)$, and postclassical narratology which is "an extension, an expansion, a broadening, a refinement" of the previous narrative theories (p. 116). Presently, the features of postclassical narratology or new narratology rely heavily on interdisciplinary and transmedial studies, cognitive approaches and unnatural narratives (Alber \& Fludernik, 2010; Olson, 2011).

Consequently, classical narratology such as Russian Formalism and French Structuralism are no longer expected to be the core of the narrative studies but the basic elements of the said theories are now used as analytical tools "to meet different requirements of culture, literature, politics, ethics, ethnics, gender, genre" of literary studies (Qiao, 2018, p. 393). Hence, the current application of narrative theories is not merely focusing on the narratological aspects of literature but also as tools for understanding complex narratives (Alber, 2013; Fludernik, 1996; Qiao, 2018; Richardson, 2006).

Primarily known as a part of cognitive narratology, unnatural narratology delves into the creation and practice of avantgarde and postmodern narratives which were neglected previously. Throughout the years, other major unnatural narratologists further tabulate the concept (Alber, 2009, 2013, 2016; Nielsen, 2004). As of now, unnatural narratology does not have a unified approach although there are two most common prepositions. Initially, Brian Richardson defined the concept as "the theory of fictional narratives that defy the conventions of nonfictional narratives and of fiction that closely resembled nonfiction" (2006, p. 385), but in later years, he no longer regarded narratives that defied the conventions of existing narratives and genres as unnatural: "...such an effect is a feature of reception, not the storyworld" (Alber \& Richardson, 2020, p. 3). The second common preposition is by Jan Alber's definition where he limited the unnatural to "physically, logically, or humanly impossible scenarios or events" (Alber et al., 2013, p. 102).

Theoretically, there are three types of unnatural narratology: unnatural 
storyworlds, unnatural minds, and unnatural acts of narration (Alber et al., 2010). For this essay, only unnatural storyworlds are focused on. Storyworlds, as Herman denoted, are "mentally and emotionally projected environments in which interpreters are called upon to live out complex blends of cognitive and imaginative response" (2005, p. 570). In other words, storyworlds refer to the surrounding that the story or narrative is built on. Naturally, storyworlds are closely related with temporal and spatial limitations, as traditional chronological narrative dictates. However, unnatural storyworlds comprise "physical or logical impossibilities that concern the represented world's temporal or spatial organization" (Alber et al., 2010, p. 116) which allows the storyworlds in literature to defy the limitations. This preposition refers to anti-chronological narratives e.g. reverse chronological narrative.

In general, reverse chronological narrative starts the story at the ending before moving backward towards the beginning. Unlike flashback which entails retelling the story by having a series of acts of narration as a method of reminiscing the past, reverse chronology is unique to the structure of the text and often manipulates narrative temporality. Literary texts such as Phillip K. Dick's Counter-Clock World (1967), Kurt Vonnegut's Slaughterhouse Five (1969) and Martin Amis' Time's Arrow (1991) are some examples of unnatural storyworlds. Even though this narrative technique is often considered as non-linear, others perceived it to be a part of linear narrative. This assumption is derived from a common conception where most narratives in reverse chronology are written following the chronological order of Z-Y-X instead of following a normal narrative sequence of A-B-C.

In this essay, Charlie Kaufman's Eternal Sunshine of the Spotless Mind (2004) (abbreviated as Eternal Sunshine) is categorized as unnatural storyworld because it portrays the reverse chronology in its narrative structure. Generally, narrative structure is rarely analysed separately because it is viewed as a tool for the author to impart and present the text's themes. Besides that, most studies of Eternal Sunshine mainly highlight the themes of personal identity and memory, and the characters' relationship (Chambers, 2011; Driver, 2009; Grau, 2006; Jess-Cooke, 2007; Reeve, 2009) instead of examining the unnaturalness of the narrative. Therefore, due to the lack of studies on its narrative structure, this essay examines the significance of reverse chronology to the screenplay. This study argues that the screenplay's unnatural narrative structure is an active process and product of the protagonist's self-redemption. Following this hypothesis, the analysis highlights the protagonist's journey through his sub-consciousness by using dramatism theory as the analytical tool.

\section{THEORY}

\section{Dramatism Theory and Terms for Order}

Kenneth Burke's dramatism theory started from literary analyses before being used in 
other interdisciplinary studies particularly in rhetoric and communication studies (Graham, 2011; Huglen \& Rountree, 2008). Burke noted that his theory should be labelled as "new rhetoric" in comparison with Aristotle's "old rhetoric" that emphasized more on "persuasion" (Burke, 1969, p. 203). According to Burke, humans are "symbolusing animals" in which language is used as "symbolic action" to transmit our meanings and purposes (1963, p. 491). In view of that, language is seen as the universal symbol system because "it enables human beings to imagine, to select, to create, and to define the situations to which they respond" (Burke, 1989, p. 8).

Social order, or as Burke phrases it, "terms for order" (1970, p. 183) started with his researches on the rhetoric of religion. Accordingly, society is formed following "the principles of negative" where order is created by fear of sins and disruption of the balance is considered as "moral disobedience", or drama (Burke, 1970, p. 187). Hence, rules and regulations are created to preserve the society in a seamless condition. Traditionally, these set of laws are based on a certain system or belief such as religion: "... and sometimes conflicting functions of religion (solace and control) worked together in the doctrines of Christianity..." (Burke, 1989, p. 280). Conversely, Burke believes that humans are indoctrinated to find similar desires from the society thus perpetuating a concept of sin and redemption. As Edward C. Appel briefly explained:
The improper, immoral, or illegal act or situation sets the stage for a drama of "redemption" aimed at setting things right once again. We put things back into "moral order" by way of "moral conflict" with the persons or forces that did the bad deed or support those that did it (2012, p. 5).

Naturally, human beings are obsessed with perfection. A similar description is also reiterated in Burke's researches. Accordingly, there are five major clauses of being human: 1) "the symbol-using (symbolmaking, symbol-misusing) animal”, 2) "inventor of the negative (or moralized by the negative)", 3) "separated from his natural condition by instruments of his own making", 4) "goaded by the spirit of hierarchy (or moved by the sense of order)", and 5) "rotten with perfection" (Burke, 1963, p. 507). This notion suggests that moral dilemma is governed by the societal, cultural norms and expectations where they are designated by the hierarchy of order.

Hierarchy, as Barry Brummett defined, is "a system of social order in which participants assume roles, rights, and responsibilities towards other participants" (1980, p. 65). Similarly, High Duncan also stated that hierarchy was expressed in the forms of drama particularly in comedy and tragedy. Therefore, he cogitated that "social order is created and sustained in social dramas through intensive and frequent communal presentations of tragic and comic roles whose proper enactment is believed necessary to community survival" (Duncan, 1985, p. ix). Mark P. Moore expanded on 
Burke's hypothesis that humans are "rotten with perfection" by explicating further on the notion:

That is, humans, as symbol-using animals who are moved by a sense of order or hierarchy, seek perfection in the logical extension of such principles as order and hierarchy through the symbols that they use to embody them. As humans perfect their logic of order and hierarchy through symbol use, they reveal that they are ultimately motivated, not by order or hierarchy, but by the principle of perfection itself (1997, p. 38).

Therefore, humans are inspired and tempted by the delusion of attaining perfection and in doing so, the illusion of order. In the same way, the concept of order directly relates to personal conflict where individuals struggle to follow through the hierarchy's commands. For instance, in a dramatistic analysis of guilt rhetoric in suicide notes, the researchers found that most of the individuals attempted to alleviate the feelings by believing "on the greater "good" that they believed they were accomplishing through their attempt to restore order" in their lives (Messner \& Buckrop, 2000, p. 15). Similarly, if the sin or guilt were to be publicized, the conflict becomes societal concern instead which allows the society to identify with the moral disorder and either embrace or reject it (Appel, 1997; Brummett, 1984; Kaylor, 2010; McLennan, 2012; Schultz, 2011).

Despite that, perfection or constant order is innately unattainable. William
H. Rueckert (1982) addressed on this phenomenon where humans would always fail to achieve order as prescribed by the hierarchy. This statement is analogous to Burke's definition of man and Christianity's "original sin" and how it is deemed as a tool to enforce guilt towards the followers (Wechsler, 1990). The rhetoric of guilt is prevalent in the society and among individuals, that they are considered as inseparable between rhetoric and identity (Eddy, 2003). Despite our incapability to achieve perfection, we may attempt to do so hence resulting in a vicious cycle of guilt and redemption: "... since what is "not there" never ends or goes on forever" (Appel, 1997, p. 383). Correspondingly, a similar process of guilt and redemption cycle is also apparent in Eternal Sunshine and this essay examines its implications to the narrative structure of the text.

\section{METHOD}

\section{Dramatistic Pentad and Guilt- Redemption Cycle}

The analysis was conducted by using close reading approach on the text. There are two objectives of this essay: 1) to identify the main pentadic ratio that governs the protagonist's actions and motives, and 2) to examine the implications of the protagonist's guilt-redemption cycle to the narrative structure of the text. As stated earlier, this essay considers Eternal Sunshine's unnatural narrative structure as a result of the protagonist's guilt and his journey to self-redemption. This is contrary to the previous studies where they considered the 
narrative's reverse chronology was to merely highlight the themes of the text. To assist with the analysis, two of the components from dramatism theory were selected as the main analytical tool: dramatistic pentad and guilt-redemption cycle.

The first objective was achieved by utilizing the dramatistic pentad which consists of five key terms: act, scene, agent, agency, and purpose. These terms can be simplified into grammatical jargons: act signifies what (action), scene signifies where and when (setting), agent signifies who (persons involved), agency signifies how (the instrument used), and purpose signifies why (motive). In hindsight, dramatistic pentad was suggested to "show how the functions which they designated operate in the imputing of motives" (Burke, 1989, p. 135). Additionally, a sixth term was introduced in Burke's revised version of $A$ Grammar of Motives where attitude was included as a part of dramatistic hexad. However, for the purpose of this study, only the original dramatistic pentad would be used as it might produce "terminological/ logological inconsistency" in the textual analysis (Anderson \& Althouse, 2010, para. 14).

Accordingly, these five pentadic terms are interchangeable but must be paired into one pentadic ratio. In the ratio, the first term directs the second term. For instance, in a scene-act ratio, scene is the dominant element that contains the act (Burke, 1969) which suggests that the actions are governed by the setting. Usually, the central pentadic ratio is identified according to the "rhetor's interpretation (or motives) of a particular situation will subscribe to the principles held by a certain philosophy" (Graham, 2011, p. 42). In other words, ratios are not fixed, as different perspectives allow different results since "no single terminology can completely sum up or reflect human experience and motive" (DePalma et al., 2008, p. 314). Corresponding to the essay's first research objective, dramatistic pentad is used to establish the central pentadic ratio of the text which then becomes the major feature for the next objective.

For the second objective, guiltredemption cycle is selected to map out the protagonist's self-redemption. According to Burke, in his description of guilt-redemption cycle: "...If action is to be our key term, then drama; for drama is the culminative form of action... But if drama, the conflict. And if conflict, then victimage" (1989, p. 125). This hypothesis suggests that ideally, when individuals are in moral disorder ("guilt"), they always pursue methods for "purification" to attain "redemption" at the end of the conflict. This guilt-redemption cycle constitutes five general elements which oversee a successive structural hierarchy: 1) "morally disordered situation or setting", 2) "guilt-obsessed actor vs. a guilty opponent or counteragent", 3) "repentant or rebellious attitude", 4) "self-sacrifice or victimage", and lastly, 5) "redemptive purposes and means" (Appel, 2012, pp. 29-31). Therefore, the next part of the analysis focuses on the protagonist's journey of self-redemption following the central pentadic ratio and guilt-redemption cycle. 


\section{RESULTS AND DISCUSSION}

\section{Framing Eternal Sunshine of the Spotless Mind}

Eternal Sunshine is a story about Joel Barish, the protagonist, as he journeys through his memory erasure procedure of his former lover Clementine Kruczynski. Upon discovering that Clementine has erased him from her memories, Joel undergoes a similar procedure. The procedure uses technology from Lacuna Inc. founded by Dr. Howard Mierzwiak and it functions by starting from Joel's recent memories that are associated with Clementine. However, as Joel ventures into his own forgotten memories, he fearfully regrets his decision as he realizes his true feelings for Clementine. Despite his efforts to stop the procedure, Joel wakes up on the next day with his memories of Clementine forgotten. Nevertheless, their paths seem to cross again when they meet each other in a train to a place where they first met.

Based on the previous studies and film reviews, most critics commend Eternal Sunshine in two aspects: its philosophical elements that stand at par with postmodern poetics (Dedulle, 2010; Holmbach, 2006) and its anti-chronological narrative structure as a tool for accentuating the themes. Despite its conception of reverse chronology, Eternal Sunshine is written in two different narrative temporality. One, the memory erasure procedure that happened in Joel's sub-consciousness occurs in reverse chronology with his recent memories moving backward to the day they met. Two, the first part of the screenplay (before the events of the procedure is shown) is set in reversal but later moves on in chronological order after the procedure.

Therefore, Eternal Sunshine stipulates itself into five main arcs: Exposition, Rising Action, Climax, Falling Action and Resolution. However, the linear order of the screenplay begins from Resolution (after the memory erasure procedure), Exposition (before and beginning of the procedure), Rising Action, Climax, Falling Action and then ends in Resolution again. Because of its complex and unnatural nature, the analysis of the screenplay will be written according to this order for clearer understanding of the story.

\section{Dramatistic Pentad in Eternal Sunshine of the Spotless Mind}

In this essay, Joel and Clementine's relationship becomes the main subject to establish the narrative's central pentadic ratio. This is needed as the ratio enables us "to discover whether the first term controls or influences the nature of the second term" (Foss, 2018, p. 374). Accordingly, Joel's actions and decisions (act) are motivated by his sense of guilt to Clementine (agent) and it is represented from their binary opposition. Rutten et al. suggest that by addressing the central binary opposition in the narrative, it enables the readers to comprehend the "dominant terms and the mismatches between terms" thus providing "a more in-depth view of how situations are named" (2012, p. 638). For instance, both film critics and reviewers label Joel as "emotionally withdrawn" due to his inability to express himself. Meanwhile, Clementine’s 
characteristics are often defined as "freespirited" and "fun-loving"; quite contrary to Joel's stoic nature. Therefore, the mismatch between these two distinct characters are transpired into agent-act ratio wherein Clementine (agent) is the dominant element in Joel's actions and decisions (act).

Throughout the story, Clementine's domineering and vibrant personality is represented from her various change of hair colors. Conversely, a number of studies associate her actions as "conscious and artificial desire to appear free and spontaneous" (Jollimore, 2009, p.53) while also act as a part of "transition points in Clementine's character development" (Donatini, 2013, p. 101). Besides that, it is also viewed as Kaufman's method to “orient us in the narrative of a relationship - a narrative that is unfolding in reverse" (White, 2009 , p. 101). George Toles drew attention to this detail from Kaufman's interview where he notified that the audiences only saw Clementine from "Joel's projections and memory constructions of her" (2009, p. 112). This is why when we are first introduced to Clementine, Joel immediately views herself as a disparity amidst his lacklustre surroundings:

He has no other thoughts, does some work on the drawing on the opposite page. He glances up, spots a female figure in the distance, walking in his direction. She stands out against the gray in a fluorescent orange hooded sweatshirt. This is Clementine. She's in her early thirties, zaftig. He watches her for a bit, then as she nears, he goes back to his drawing, or at least pretends to. Once she has passed, he watches her walk away (Kaufman, 2004, p. 2).

The above excerpt begins in Resolution arc, the morning after Joel's memory erasure procedure. And yet, Joel finds himself unknowingly attracted to Clementine because in the past, the "fluorescent orange hooded sweatshirt" was worn by her multiple times and he loved seeing her in it (Kaufman, 2004, pp. 44, 70, 139). This is one of the earliest instances of agent-act ratio when Joel's acts are influenced by Clementine. In addition, when Clementine later invites him over to her apartment, Joel does not entirely refuse (Kaufman, 2004, p. 16). His decision then creates a chain of reaction as he finds himself willingly following her suggestions (Kaufman, 2004, pp. 22, 113). Then in Exposition arc, when Joel discovers about Clementine's decision (Kaufman, 2004, p. 31), this revelation causes him to undergo the similar procedure (Kaufman, 2004, p. 34). As the procedure begins, his recent memory shows moments of their argument, which leads to the reasoning behind his action:

JOEL: (screaming) Look at it out here. It's falling apart. I'm erasing you. And I'm happy. You did it to me first. I can't believe you did this to me. (yelling after her) By morning you'll be gone! Ha! You hear me? You'll be gone! A perfect ending to this piece of shit story! (Kaufman, 2004, pp. 44-45).

In a linear order, this scene acts as the catalyst of the moral disorder. Their argument 
subsequently leads to Clementine's memory erasure procedure and Joel's decision. Retrospectively, memory erasure procedure can be considered as an immoral act as it can be taken advantage of (Driver, 2009, p. 81). However, whether the act is deemed as acceptable depends on the context. At first, their actions are appropriated to "erase painful memories". But in this context, Joel feels emotionally harmed after discovering Clementine's action, thus allowing him to act equally: "But if the other person is harmed, as Joel seems to have been, then that harm would at least have to be weighed in the balance" (Driver, 2009, p. 81). Therefore, based on Joel's understanding, his decision to erase Clementine from his memories is an act of retaliation to restore the balance.

However, as he ventures deeper into his sub-consciousness, Joel has to relive their best memories too. This is depicted later in Rising Action arc when Joel is presented with (or rather, remember) their quiet, impassioned moments together (Kaufman, 2004, pp. 56-57, 61). This realization then causes Joel to change his initial opinion: "You're erasing Clementine! Right? I love her! But I won't when I wake up ... right? I won't know her, so... please, just leave me alone! Please" (Kaufman, 2004, p. 62). In regard to this, Troy Jollimore pinpointed that our "cognitive abilities are finite" and regardless of our attempts, we may forget certain and many memories until "what is remembered is remembered only partially, incompletely, and frequently inaccurately" (Jollimore, 2009, p. 34). Due to their previous happy memories, Joel is influenced again, indirectly by Clementine, to stop the procedure.

Following this, Joel attempts a desperate measure by hiding Clementine within his childhood memories. His action, like the others, is also prompted by Clementine: "So what if you take me somewhere else, somewhere where I don't belong? And we hide there till morning" (Kaufman, 2004, p. 67). Even though Clementine in his sub-consciousness is his projection of her real self, this does not imply that Joel is the instigator. In a number of occasions shown in Joel's memories, Clementine is depicted as the dominant one in their relationship (Kaufman, 2004, p. 47, 53) and later in Resolution arc, Clementine compels him to revisit Charles River at the same day they meet in the train (Kaufman, 2004, p. 115). Based on this observation, the real Clementine might possibly incite similar suggestions to Joel.

Even so, their attempts are proven unsuccessful as shown in Falling Action arc where Joel is forced to accept the consequences of his previous actions and decisions. Similarly, this is also influenced by Clementine: "Come back and make up a good-bye at least. Let's pretend we had one" (Kaufman, 2004, p. 105). Since this is their final memory before being permanently erased, both Joel and Clementine are prompted to say goodbye after the "adventure of their lives" (Day, 2011, p. 138). Their short good-bye, albeit a fabrication made by his mind is proven expedient because soon after he awakes the 
next day, he is compelled to board the train to the beach where they first met and then encounter her again.

From these instances, Joel's decisions are integrally governed by Clementine. This is because with her, Joel achieves a sense of comfort or order. Only when he is faced with a life without her, his situation becomes morally disordered. Burke states that human beings are always in need of perfection and in this situation, Joel seeks for the same thing from Clementine. Despite of his incapability for emotional connection, Clementine accepts his flaws thus making him dependent on her. Andy Miah addressed on this co-dependence: "Their incompleteness of character and the voids in their memories connect the overarching narrative about the importance of experiencing loss in life and the value of conflict in human relationships" (2008, p. 142).

Therefore, based on these findings, the agent-act ratio is identified and subsequently established the narrative structure of Eternal Sunshine. Fundamentally, agent-act ratio refers to how an individual may influence the action of another individual. In this context, Clementine is the individual (agent) who governs Joel's actions (act). Conversely, the unnatural narrative structure in Eternal Sunshine follows anti-chronological narrative structure, symbolically referring to Joel and Clementine's distorted relationship. As the story begins with the Resolution arc where Joel encounters Clementine again, it provides parallelism to Joel's dependence on Clementine as the cycle continues. Throughout the narrative, Clementine is present in his every action and decision-making, directly shaping his guilt-redemption cycle.

\section{Guilt-Redemption Cycle in the Unnatural Narrative Structure}

To oversee Joel's guilt-redemption journey, the unnatural narrative structure of Eternal Sunshine is arranged following the five elements of guilt-redemption cycle as Edward C. Appel (2012) has prescribed. As a part of dramatism theory, this cycle is defined according to the five elements of dramatistic pentad but for Appel's version, he adds attitude following Burke's later version of dramatistic hexad. As a result, scene acts as the first element: "morally disordered situation or setting"; agent as the second element: "guilt-obsessed actor vs. a guilty opponent or counteragent"; attitude as the third element: "repentant or rebellious attitude"; agency as the fourth element: "self-sacrifice or victimage"; purpose as the fifth element: "redemptive purposes and means" (Appel, 2012, pp. 2931). However, since attitude is not a part of this study's dramatistic pentad, the third element "repentant or rebellious attitude" is equivalent to pentadic term act with its function as an attribution of the "incipient act" (Burke, 1969, p. 20). Thus, for this study, it refers to act instead.

Accordingly, the five elements in the cycle must be present in order for the protagonist to reach the final stage, redemption wherein it acts as the purpose or end result for their struggle. Therefore, there 
are various utilization of guilt-redemption cycle according to the dramatistic pentad or hexad. For example, Chelsea J. McLennan's dramatistic process established scene and act first before moving to agent, agency and then purpose (McLennan, 2012, p. 83). This difference might be caused by McLennan's findings of her study's central agent-agency ratio. Nevertheless, this does not indicate that her process is incorrect because there is no clear right or wrong method in establishing pentadic ratio. Burke himself has given his opinion on this matter:

The ratios may often be interpreted as principle of selectivity rather than as thoroughly causal relationships. That is, in any given historical situation, there are persons of many sorts, with a corresponding variety in the kinds of acts that would be most representative of them (Burke, 1969, p. 18).

Thus, this analysis follows the revised version of Appel's guilt-redemption cycle. Following the structure, the first element of guilt-redemption cycle starts with the setting (scene). In Eternal Sunshine, this is signified as Joel's sub-consciousness. As most of the major events occur while he is asleep, the scene is positioned in his sub-consciousness as he jumps into numerous memories. Because of his desire to erase Clementine, this subsequently imposes a sense of guilt in him. Likewise, it then evokes epiphany in him as he realizes the immorality of his decision particularly in his method to attain order is by going back to his previous hierarchy without Clementine.
According to Appel, "morally disordered" setting is where "the constraining environment in which the action takes place, harmonized initially in an uneasy fashion by rules that might be broken, then, almost inevitably, disrupted by disobedience" (2012, p. 29). In Joel's circumstance, his life becomes disordered after Clementine deleted her memories. Then during the procedure, Joel's mind becomes disordered specifically when his erased memories are now merely described as "decayed scenes" (Kaufman, 2004, p. 61) and repeatedly stated to be faded and dissolved. In the screenplay, "decayed" refers to Joel's memories being deteriorated and festered by Lacuna Inc.'s technology. However, it also symbolizes Joel's own guilt as it poisons himself after he understands his true feelings to Clementine.

In the following stage, Joel embodies the second element of guilt-redemption cycle by becoming the "guilt-obsessed actor" (agent) while Clementine becomes his "guilty opponent". Clementine, as it has established earlier, signifies agent who influences Joel's actions and decisions, and ultimately his motives. Appel proposes that the characteristics of "guilt-obsessed actor" and "guilty opponent" may be identified as simpler terms: protagonist and antagonist (2012, pp. 29-30) and it refers to the situation where "the offended against the supposed offender" (2012, p. 29). In this analysis, Joel is guilt-ridden for his decision to memory erasure, and yet, Clementine is the one who beckons him to it: "You erased 
me first. It's the only reason I'm doing it" (Kaufman, 2004, p. 66).

Despite his latter resolution, Joel's former decision to erase Clementine is a result from her betrayal. Therefore, his action indicates the third element of the guilt-redemption cycle: "repentant or rebellious attitude" (act) which refers to the "manner in which the action is carried out, based on the openly displayed, or sometimes hidden or partly hidden" (Appel, 2012, p. 30). At first, this supposition is shown in Joel's initial interpretation of Clementine's decision as a punishment for his honesty (Kaufman, 2004). Afterwards, when he 'confronts' and blames Clementine in his memories, his guilt is partially alleviated although he was the perpetrator of their last dispute (Kaufman, 2004).

However, Joel's anger and frustration towards Clementine then transform into sense of guilt. This change is sparked upon his discovery over their previous exchange of her personal struggles and their other affectionate memories (Kaufman, 2004). Therefore, his decisions to stop the procedure indicate his attempts to purify himself from his guilt. Following this, Joel's "rebellious attitude" reforms to "repentant attitude" as he acts against Lacuna Inc.'s machine. As a result, the fourth element of guilt-redemption cycle is then ascertained: "self-sacrifice or victimage" (agency). This particular element also signifies the fourth stage of Joel's self-redemption journey and it requires him to act according to a specific approach prescribed by Burkean frames.
Guilt, as Brummett posited, is a powerful emotion and must be extinguished:

Guilt is an awareness that the carefully woven fabric of identifications upheld in hierarchy has been torn through what one has done or thought. Guilt is a powerful motive because it threatens a lapse into uncontrolled mystery. Guilt must be expiated, and the person or group must achieve redemption that leads back to a secure hierarchy (reinstatement of the old or establishment of a new one) (1981, p. 255).

To expiate guilt, Burke postulates three separate methods: self-sacrifice (mortification), victimage (scapegoating) and later transcendence (re-classifies the sins according to the society's "frames of acceptance") (Brummett, 1982; Burke, 1970, 1989). Formerly, Joel's initial "rebellious attitude" denounces Clementine (Kaufman, 2004, p. 66) and his actions are viewed as a method to victimage Clementine in an attempt to alleviate his sense of guilt. This supposition mirrors Joel's denial of his guilt: "By projecting an internal conflict onto an external symbolic bearer of that conflict and by then symbolically eliminating the scapegoat, a person could avoid recognizing a self-identity contaminated by internal conflict" (Eddy, 2003, p. 63).

However, his stance changes directly after he asks for Clementine's aid (Kaufman, 2004, p. 67) which indicates mortification instead. His decision to hide Clementine in his childhood memories is suggested as his chosen method to seek redemption: 
if he saved Clementine, he is absolved from his misdeeds as well. This hypothesis corresponds to Rueckert's recapitulation on guilt-redemption cycle and its significance to one self:

Failure or disobedience - the 'fall' - cause guilt, which in turn makes necessary the whole machinery of catharsis. The two principal means of purification are mortification and victimage; and the end result of both is redemption, or the alleviation of guilt" (1982, p. 131).

In regard to guilt, Joel's sentiments are not temporary. As he moves further into his memories, his sense of guilt heightens and affects his sub-consciousness as he jumps from one childhood memory to another. Furthermore, his guilt is prolonged because he faces with the probability of losing Clementine forever: "I don't want to lose you, Clem" (Kaufman, 2004, p. 68). Therefore, the farther he gets, the further his sense of guilt permeates his whole existence. And yet, Joel's self-sacrifice is never seen as a risky decision because he is unaware of the consequences. In spite of his efforts, Joel fails to save Clementine and also destroys his own childhood memories: "After a long moment of no reaction from Clementine, Joel pulls the pillow from her face. She is gone. His childhood house is crumbling" (Kaufman, 2004, p. 82). C. D. C Reeve pinpoints that when Joel brings Clementine to his childhood memories, the traces of Clementine while she is in there are picked by Lacuna Inc.'s technology, thus deleting his personal memories too:
Because Clementine told Joel about her doll in a moment of intimate selfdisclosure, when Lacuna erased Joel, her memory of her doll-like Joel's memory of his doll - had to go too. "Any association" is Mierzwiak's formula for what to target (Reeve, 2009, p. 18).

Despite that, in his journey of purification, Joel is likely successful. By self-sacrificing, Joel has accepted his mistakes and finally able to reach the fifth and final element and stage of guiltredemption cycle: "redemptive purposes and means" (purpose). Appel justified this stage as "the good that comes out of the bad, the gain after the pain, and the preliminary steps, stages, and tools of action required to bring this glorious vision to pass" (2012, p. 31 ). For Joel, the end result or purpose of his redemption journey is to alleviate himself from the guilt. This is portrayed later at the end of Joel's memories of Clementine when he accepts the inevitability of the memory erasure procedure and letting her go: "Enjoy it. Say goodbye” (Kaufman, 2004, p. 101).

Based on this analysis, Joel completes his guilt-redemption cycle by undergoing mortification or self-sacrifice. Due to its structure that begins anti-chronologically, Eternal Sunshine manages to capture the complexity of their turbulent relationship and his redemption journey. Ultimately, the unnatural narrative structure of Eternal Sunshine symbolizes the deterioration of Joel's hierarchal order as he retraces his steps back to Clementine. This supposition is reflected in the final part of the screenplay 
when he decides to restart their relationship (Kaufman, 2004, p. 129). This action may be influenced by his previous sense of affection towards Clementine; something so abstract that Lacuna Inc.'s technology is unable to detect. Or perhaps Joel is still under Clementine's influence as she is the one who suggested him to keep trying, thus strengthening the central agent-act ratio in the unnatural narrative structure of Eternal Sunshine:

JOEL: I still thought you were going to save me. Even after that.

\section{CLEMENTINE: I know.}

JOEL: It would be different, if we could just give it another go around.

CLEMENTINE: Remember me. Try your best. Maybe we can. (2004, p. 97)

\section{CONCLUSION}

From the findings, it is established that the central pentadic ratio agent-act governs not only the protagonist but also the narrative structure of Eternal Sunshine. Throughout the text, Clementine (agent) influences Joel's actions and decisions (act) and this is transpired in the text's unnatural narrative structure. As Joel moves further away from his previous hierarchy, the narrative structure reflects the disorderly manner of his mind, equivalent to the narrativity process of cognitive narratology. Conversely, this study is done to prove that anti-chronological narrative may not only function as the framework of the narrative structure but also as the juxtaposition of the protagonist's motives as well. From the dramatistic analysis of Eternal Sunshine, the outcomes shift the perspective of interpretation by focusing on Joel's redemption journey thus subsequently contributing to the scholarship of the literary analyses of the text.

In addition, the five elements of guilt-redemption cycle provide clearer comprehension of Joel's motive and fundamentally, the understanding of the text as a whole. This study intends to reinvigorate dramatism theory as analytical tool that could be utilized by students and scholars alike to comprehend and understand unnatural literary texts better. Unnatural texts such as Eternal Sunshine may benefit from dramatism theory because it allows us to study and interpret complex literature from technical and narratological aspects. Even though dramatism theory has since branched out to communication, rhetorical and social studies (Dunn, 2018; Griffiths \& Cos, 2007; Kirk, 2015; Langenbach. 2019; McLennan, 2012; Mills, 2014), its foundation started with literary analyses and it is part of this study's aims to reutilize dramatism theory as analytical tool for literature studies. In conclusion, dramatism theory may indeed provide another perspective in analysing the intricateness of unnatural narrative structure in literary texts.

\section{ACKNOWLEDGEMENT}

This work was supported by Geran Putra Berimpak 2018 (UPM/800-3/1/ GPB/2018/9660100) from Universiti Putra Malaysia (UPM). 


\section{REFERENCES}

Alber, J. (2009). Impossible storyworlds-and what to do with them. Storyworlds: A Journal of Narrative Studies, 1, 79-96. https://doi. org/10.1353/stw.0.0008

Alber, J. (2013). Unnatural narratology: The systematic study of anti-mimeticism. Literature Compass, 10(5), 449-460. https://doi.org/10.1111/ lic3.12065

Alber, J. (2016). Unnatural narrative: Impossible worlds in fiction and drama. University of Nebraska Press. https://doi.org/10.2307/j. ctt1d4v147

Alber, J., \& Fludernik, M. (Eds.). (2010). Postclassical narratology: Approaches and analyses. The Ohio State University Press.

Alber, J., Iversen, S., Nielsen, H. S., \& Richardson, B. (2010). Unnatural narratives, unnatural narratology: Beyond mimetic models. Narrative, 18(2), 113-136. https://doi.org/10.1353/ nar.0.0042

Alber, J., Iversen, S., Nielsen, H. S., \& Richardson, B. (2013). What really is unnatural narratology? Storyworlds: A Journal of Narrative Studies, 5, 101-118. https://doi.org/10.5250/ storyworlds.5.2013.0101

Alber, J., \& Richardson, B. (Eds.). (2020). Unnatural narratology: Extensions, revisions, and challenges. The Ohio State University Press. https://doi.org/10.26818/9780814214190

Anderson, F. D., \& Althouse, M. T. (2010). Five fingers or six? Pentad or hexad? KB Journal, 6(2).

Appel, E. C. (1997). The rhetoric of Dr. Martin Luther King, Jr.: Comedy and context in tragic collision. Western Journal of Communication, 61(4), 376-402. https://doi. org/10.1080/10570319709374586
Appel, E. C. (2012). Language, life, literature, rhetoric and composition as dramatic action: $A$ Burkean primer. OarPress.

Brummett, B. (1980). Symbolic form, Burkean scapegoating, and rhetorical exigency in Alioto's response to the "zebra" murders. Western Journal of Speech Communication, 44(1), 64-73. https:// doi.org/10.1080/10570318009373987

Brummett, B. (1981). Burkean scapegoating, mortification, and transcendence in presidential campaign rhetoric. Central States Speech Journal, 32(4), 254-264. https://doi. org/10.1080/10510978109368104

Brummett, B. (1982). Burkean transcendence and ultimate terms in rhetoric by and about James Watt. Central States Speech Journal, 33(4), 547-556. https://doi.org/10.1080/10510978209388461

Brummett, B. (1984). Burkean comedy and tragedy, illustrated in reactions to the arrest of John Delorean. Central States Speech Journal, 35(4), 217-227. https://doi. org/10.1080/10510978409368191

Burke, K. (1963). Definition of man. The Hudson Review, 16(4), 491-514. https://doi. org/10.2307/3848123

Burke, K. (1969). A grammar of motives. University of California Press.

Burke, K. (1970). The rhetoric of religion: Studies in logology. University of California Press.

Burke, K. (1989). On symbols and society. University of Chicago Press.

Chambers, S. A. (2011). Charlie Kaufman, philosophy, and the small screen. In D. LaRocca (Ed.), The philosophy of Charlie Kaufman (pp. 155-168). University Press of Kentucky.

Day, W. (2011). I don't know just wait: Remembering remarriage in Eternal Sunshine of the Spotless Mind. In D. LaRocca (Ed.), The philosophy of 
Charlie Kaufman (pp. 132-154). University Press of Kentucky.

Dedulle, M. (2010). 'Change is not a choice': An analysis of the poetics of Charlie Kaufman, based on 'Being John Malkovich', 'Adaptation.' and 'Synecdoche, New York' [Master's thesis, Ghent University]. Ghent University.

DePalma, M. J., Ringer, J. M., \& Webber, J. (2008). (Re) charting the (dis)courses of faith and politics, or rhetoric and democracy in the Burkean barnyard. Rhetoric Society Quarterly, 38(3), 311-334. https://doi.org/10.1080/02773940802167575

Donatini, H. T. (2013). Spotless minds and cultural memory: Teaching future teachers in the United States. Digital Defoe: Studies in Defoe \& His Contemporaries, 5(1), 95-105.

Driver, J. (2009). Memory, desire, and value. In C. Grau (Ed.), Eternal sunshine of the spotless mind (pp. 80-93). Routledge.

Duncan, H. D. (1985). Communication and social order. Routledge.

Dunn, R. C. (2018) "The future is in good hands": A pentadic analysis of president Barack Obama's farewell address. Kaleidoscope: A Graduate Journal of Qualitative Communication Research, 17(7), 73-89.

Eddy, B. (2003). The rites of identity: The religious naturalism and cultural criticism of Kenneth Burke and Ralph Ellison. Princeton University Press.

Fludernik, M. (1996). Towards a 'natural'narratology. Routledge.

Fludernik, M., \& Pirlet, C. (2012). Narratology. In M. Middeke, T. Müller, C. Wald \& H. Zapf (Eds.), English and American Studies (pp. 225-230). Springer. https://doi.org/10.1007/978-3-47600406-2_13

Foss, S. K. (2018). Rhetorical criticism: Exploration and practice. Waveland Press Inc.
Graham, D. C. (2011). Kenneth Burke's pentad: A state of the discipline review, 2001-2010. [Master's thesis, California State University]. California State University.

Grau, C. M. (2006). Eternal Sunshine of the Spotless Mind and the morality of memory. Journal of Aesthetics and Art Criticism, 119-133. https:// doi.org/10.1111/j.0021-8529.2006.00234.x

Griffiths, C., \& Cos, G. (2007). A tendency to incite: Applying Kenneth Burke's pentad to Cohen v. California. RIT Scholar Works, 191-237.

Herman, D. (2005). Storyworlds. In D. Herman, M. Jahn \& M.-L. Ryan (Eds.), Routledge encyclopedia of narrative theory (pp. 569-570). Routledge. https://doi.org/10.4324/9780203932896

Holmbach, J. (2006). A metaphysical can of worms: A poetics of postmodernism in the works of Charlie Kaufman. [Master's thesis, Aalborg University]. Aalborg University.

Huglen, M., \& Rountree, J. C. (2008). Editors' essay: The future of Burke studies. KB Journal, 4(2).

Jess-Cooke, C. (2007). Narrative and mediatized memory in Eternal Sunshine of the Spotless Mind. [Master's thesis, University of Sunderland]. University of Sunderland.

Jollimore, T. (2009). Miserably ever after: Forgetting, repeating and affirming love. In C. Grau (Ed.), Eternal sunshine of the spotless mind (pp. 3161). Routledge.

Kaufman, C. (Screenwriter), \& Gondry, (Director). (2004). Eternal Sunshine of the Spotless Mind [Film]. Focus Features.

Kaylor, B. T. (2010). Savior, fool or demagogue: Burkean frames surrounding the ten commandments judge. KB Journal, 6(2).

Kirk, R. T. (2015). The buck stops in Benghazi: A practical application of the dramatistic pentad and interpersonal deception theory. [Master's thesis, Liberty University]. Liberty University. 
Langenbach, M. S. (2019). The tragedy of the gamer: A dramatistic study of GamerGate. [Master's thesis, Auburn University]. Auburn University.

McLennan, C. J. (2012). Guilt and redemption in a national eulogy: President Obama's "Together We Thrive: Tucson and Arizona" address as a call for mortification. [Master's thesis, Oregon State University]. Oregon State University.

Meister, J. C. (2014). Narratology. In P. Hühn, J. Pier, W. Schmid \& J. Schönert (Eds.), The Living Handbook of Narratology (pp. 329-350). Walter de Gruyter. https://doi. org/10.1515/9783110316469

Messner, B. A., \& Buckrop, J. J. (2000). Restoring order: Interpreting suicide through a Burkean lens. Communication Quarterly, 48(1), 1-18. https://doi.org/10.1080/01463370009385575

Miah, A. (2009). 'Blessed are the forgetful': The ethics of memory deletion in Eternal Sunshine of the Spotless Mind. In S. Shapshay (Ed.), Bioethics at the Movie (pp. 137-155). Johns Hopkin University Press.

Mills, T. (2014). Using Burke's dramatism to unpack intractable conflict: Bush 43 and the process of peace in the Middle East. [Doctoral dissertation, Georgia State University]. Georgia State University.

Moore, M. P. (1997). Rhetorical subterfuge and "the principle of perfection," part ii: Bob Packwood's senate resignation. The Southern Communication Journal, 63(1), 37-55. https:// doi.org/10.1080/10417949709373076

Nielsen, H. S. (2004). The impersonal voice in first-person narrative fiction. Narrative, 12(2), 133-150. https://doi.org/10.1353/nar.2004.0002

Olson, G. (2011). Current trends in narratology. Walter de Gruyter.

Prince, G. (2008). Classical and/or postclassical narratology. L'Esprit Créateur, 48(2), 115-123. https://doi.org/10.1353/esp.0.0005
Qiao, G. (2018). When narratology does not travel well: Introduction. Neohelicon. 45, 393-399. https://doi.org/10.1007/s11059-018-0457-6

Reeve, C. D. C. (2009). Two blue ruins: Love and memory In C. Grau (Ed.), Eternal Sunshine of the Spotless Mind (pp. 15-30). Routledge.

Richardson, B. (2006). Unnatural voices: Extreme narration in modern and contemporary fiction. The Ohio State University Press.

Rueckert, W. H. (1982). Kenneth Burke and the drama of human relations. University of California Publishing.

Rutten, K., Roets, G., Soetaert, R., \& Roose, R. (2012). The rhetoric of disability: A dramatisticnarrative analysis of One Flew over the Cuckoo's Nest. Critical Arts: South-North Cultural and Media Studies, 26(5), 631-647. https://doi.org/ $10.1080 / 02560046.2012 .744720$

Schultz, P. D. (2011). A rhetoric of retribution and redemption: Burke's term for order in the drama of child sexual abuse. International Journal of Law and Psychiatry, 34, 168-176. https://doi. org/10.1016/j.ijlp.2011.04.009

Toles, G. (2009). Trying to remember Clementine. In C. Grau (Ed.), Eternal Sunshine of the Spotless Mind (pp. 111-157). Routledge.

Wechsler, H. J. (1990). What's so bad about guilt? Learning to live with it since we can 't live without it. Simon and Schuster.

White, S. L. (2009). Michel Gondry and the phenomenology of visual perception. In C. Grau (Ed.), Eternal Sunshine of the Spotless Mind (pp. 94-110). Routledge. 
